\title{
THE MINDSET OF CHRIST AS THE FOUNDATION OF THE CHURCH IN BUILDING RELIGIOUS HARMONY: AN INTERPRETATION OF PHILIPPIANS 2: 5
}

\author{
DAIDO TRI SAMPURNALUMBAN RAJA
}

Institut Agama Kristen Negeri (IAKN) Palangka Raya. JI. Tampung Penyang No.KM.6 Menteng, Kec. Jekan Raya, Kota Palangka Raya, Kalimantan Tengah. Email: daidolumbanraja@gmail.com

\begin{abstract}
Building religious harmony is the duty and responsibility of all Indonesian people. Church is an essential part of Indonesian society which is also obliged to develop religious harmony. Answering the question of how the church should behave and act in a pluralistic society is to offer the teaching concept of the mindset of Christ. As it is contained in Philippians 2: 5, the church has to serve as the foundation of religious harmony. The mindset of Christ in question is the act of Christ who does not defend his rights, the act of Christ who willingly becomes the same as an ordinary man and the act of Christ who takes the form of a slave and acts like a slave who cares for the interests of his master. This study utilizes technical data analysis with a descriptive-interpretive model, which is to elaborate the focus of the study by parsing and re-interpreting it in a certain context. In this case the text described is Philippians 2: 5 using the hermeneutic method as a scalpel and then interpreted in the context of religious harmony in Indonesia.
\end{abstract}

KeY WorDs: harmony, religion, mindset of Christ, Philippians 2: 5, church

\section{MINDSET KRISTUS SEBAGAI LANDASAN GEREJA DALAM MEMBANGUN KERUKUNAN UMAT BERAGAMA: SUATU TAFSIR TERHADAP SURAT FILIPI 2: 5}

\begin{abstract}
Abstrak
Membangun kerukunan umat beragama merupakan tugas dan tanggungjawab seluruh rakyat Indonesia. Gereja merupakan salah satu bagian dari masyarakat Indonesia yang juga berkewajiban untuk berkontribusi mewujudkan kerukunan umat beragama. Menjawab pertanyaan bagaimana gereja harus bersikap dan bertindak di tengah lingkup masyarakat yang majemuk adalah dengan menawarkan konsep pengajaran mengenai mindset Kristus yang terkandung dalam surat Filipi 2:5 untuk dijadikan sebagai landasan gereja membangun kerukunan umat beragama. Mindset Kristus yang dimaksud adalah tindakan Kristus yang tidak mempertahankan haknya, tindakan Kristus yang dengan rela menjadi sama dengan manusia dan tindakan Kristus yang mengambil rupa hamba dan berlaku seperti hamba yang mementingkan kepentingan tuannya. Penelitian ini menggunakan teknis analisis data dengan model deskripitf-interpretatif yaitu mengelaborasi fokus penelitian dengan cara mengurai dan memaknai kembali pada konteks tertentu. Dalam hal ini teks yang diurai adalah surat Filipi 2:5 menggunakan metode hermeneutik sebagai pisau bedah lalu dimaknai pada konteks kerukunan umat beragama di Indonesia.
\end{abstract}

KATA KUNCI: kerukunan, agama, mindset kristus, filipi 2:5, gereja

* Naskah diterima Maret 2021, direvisi April 2021, dan disetujui untuk diterbitkan Mei 2021

Dialog, 44(1), 2021, 67-74

https://jurnaldialog.kemenag.go.id,p-ISSN: 0126-396X, e-ISSN: 2715-6230

This is open access article under CC BY-NC-SA-License

(https://creativecommons.org/license/by-nc-sa/4.0/)

Dialog Vol. 44, No.1, Juni 2021 


\section{A. Pendahuluan}

Kerukunan umat beragama adalah salah satu bagian terpenting dari kerukunan Indonesia sebagai sebuah bangsa yang beragama. Harapan Indonesia untuk hidup rukun dan damai akan sangat sulit diwujudkan tanpa kerukunan umat beragama. Agama dapat menjadi sesuatu yang merekatkan, jika ajaran agama itu diamalkan dengan konsekuen sesuai dengan kaidahnya tanpa dipengaruhi oleh sesuatu hal yang dapat merusak tatanan dari agama tersebut. Pada masyarakat yang heterogen, agama sebagai sistem merupakan acuan nilai yang dapat mengarah kepada konflik dan disintegrasi sosial, kecuali apabila umat beragama dapat mengembangkan penafsiran keagamaan yang mempertemukan kesamaan pada masing-masing sistem acuan tersebut (Suwariyati, 2011).

Lukmanul Hakim mengutip pernyataan Mujiburrahman mengenai sebuah keadaan yang sedang marak mengenai konflik bernuansa SARA, yang muncul antara agama yang satu dengan agama yang lain (padahal belum tentu konflikkonflik tersebut adalah konflik keagamaan) dan menjadikan kerukunan umat beragama terancam pada akhirnya berakibat pada kehidupan bernegara sebagai warga Negara Kesatuan Republik Indonesia (NKRI) (Hakim, 2011). Banyak konflik yang dipicu oleh persoalan agama yang mengarah kepada sentimen keagamaan dalam ranah politik praktis, saling menghina dan melecehkan baik secara verbal maupun nonverbal. Bahkan sampai ada tindakan anarkis dengan membakar tempat-tempat ibadah yang sebenarnya dilindungi oleh pemerintah. Hal ini sangat berdampak negatif dan mempengaruhi kerukunan umat beragama, sehingga akan muncul perasaan saling mencurigai dan saling membenci (Arifianto, 2020).

Gereja sebagai lembaga yang memayungi umat Kristiani, memiliki tanggung jawab yang sama dalam membangun kerukunan umat beragama di Indonesia. Realitas di Indonesia yang tidak dapat dipungkiri adalah kenyataan terhadap kemajemukan masyarakatnya. Konteks ini dapat menjadi acuan bagi gereja-gereja di Indonesia (Titaley, 2013). Gereja merupakan salah satu agen yang menentukan akan kestabilan politik di masyarakat dan negara. Karena itu, gereja sangat penting menyadari perannya di tengah masyarakat (Aritonang, 2019).
Tidak dapat dipungkiri bahwa pemimpin gereja terdahulu pernah melakukan kesalahan yang berdampak negatif bagi hubungan atau relasi antara gereja dengan masyarakat. Banyak faktor yang merusak relasi ini, semisal pada era gereja fundamental, adanya indikasi kekeliruan dalam memahami dan mengamalkan panggilan misi gereja dalam konteks kemajemukan agamaagama. Banyak orang Kristen tidak memahami secara holistik arti misi dalam Alkitab, kalimat yang sering dibicarakan dalam kegiatan KKR (kebaktian kebangunan rohani) mengenai ladang telah menguning siap untuk dituai, menggiring pemahaman umat Kristen Indonesia untuk melakukan kristenisasi, mengajak seseorang untuk masuk menjadi anggota gereja. Faktor lainnya adalah eksklusivisme gereja, pengajaran yang cenderung mengarah pada keberhasilan sebuah gereja merupakan tujuan utama. Keberhasilan dan kesuksesan gereja ditentukan oleh kuantitas, gereja cenderung menjadi tujuan di dalam dirinya sendiri, kuantitas anggota jemaat menentukan berhasil atau tidaknya sebuah gereja (Hale, 2016).

Melihat dari kasus-kasus yang pernah terjadi terkait ketegangan antar umat beragama di Indonesia yang mengakibatkan terancamnya kerukunan umat beragama, serta melihat pada kenyataan yang ada bahwa masih minimnya kesadaran umat kristiani dalam memahami dan menyikapi posisi gereja di tengah masyarakat Indonesia yang majemuk, maka penulis melakukan usaha untuk mengkaji salah satu teks Alkitab yaitu surat Filipi 2 ayat 5, yang diharapkan hasil kajiannya akan menambah referensi sebagai landasan gereja untuk membangun kerukunan umat beragama, bagaimana seharusnya kehadiran gereja dapat diterima secara utuh dan mampu untuk hidup berdampingan dalam konteks masyarakat majemuk, kemudian bagaimana gereja dapat bekerjasama dengan lembaga agama lain, saling berupaya memperkecil ketegangan atau konflik-konflik keagamaan.

\section{B. Metode Penelitian}

Penelitian ini merupakan penelitian kualitatif dengan mengambil model penelitian kepustakaan (library research). Model penelitian kepustakaan adalah model penelitian yang sumber datanya mengacu atau menggunakan referensi 
kepustakaan berupa buku, jurnal, artikel yang terkait dengan tema penelitian. Pendekatan kepustakaan adalah pendekatan yang sah dan lumrah dalam kajian tafsir teks ayat suci (Harahap, 2014). Teknik pengumpulan data dilakukan dengan teknik dokumentasi terhadap data-data seputar objek material. Data tersebut didapat dari berbagai lilterasi seputar tafsiran surat Filipi dan juga mengenai kerukunan umat beragama, antara lain: The Story Of God Bible Commentary-Philippians; The Expositor's Bible Commentary-Ephesians, Phlippians, Colossians, Philemon; Commentary On Philippians; Understanding The Bible Commentary SeriesPhilippians; Philippians-Christ, The Source Of Joys and Strength; Philippians-Let Us Rejoice Being Conformed To Christ; Perjanjian Baru Interlinier Yunani - Indonesia dan Korkondansi Perjanjian Baru (PBIK); Mozaik Moderasi Beragama Edisi Pertama; Jurnal Harmoni Volume X: Kerukunan dan Pluralitas dalam Tantangan; Religiositas Di Alinea TigaPluralisme, Nasionalisme dan Transformasi AgamaAgama.

Teknik analisis data dilakukan dengan model deskriptif-interpretatif, model ini menekankan pada elaborasi fokus penelitian dengan cara mengurai dan memaknai kembali pada konteks tertentu. Berdasarkan fokus permasalahan, penulis akan mengkaji surat Filipi 2: 5 dengan menggunakan metode-metode hermeneutik sebagai pisau bedah dalam penelitian ini.

\section{Hasil dan Pembahasan}

Mengawali bagian ini penulis membahas secara singkat gambaran alir dari surat Filipi dan gambaran umum mengenai konteks jemaat di Filipi pada saat surat ini ditulis oleh Paulus. Pada bagian pembuka (Flp. 1: 1-11) seperti biasanya dalam surat-surat Paulus yang lain berisikan salam, ucapan syukur dan doa syafaat untuk gereja atau jemaat. Dalam doanya (Flp. 1: 9-11) terkandung harapan agar jemaat Filipi semakin diberkahi dalam pengetahuan, dalam segala macam pengertian yang benar; agar jemaat dapat berlaku setia untuk menyambut hari Kristus serta mencapai buah kebenaran. Segmen ini mencatat bahwa Paulus sedang berada di dalam penjara, dengan maksud agar memperjelas tentang kemajuan Injil kepada semua orang (Flp. 1:12-13). Paulus menanggung penderitaan dalam pelayanan, tetapi di pihak lain terdapat orang- orang yang memberitakan Injil dengan maksud yang tidak murni. Mereka memberitakan Injil dengan maksud untuk memperberat penderitaan Paulus (Flp. 1:17) (Marxsen, 2015).

Filipi adalah sebuah kota yang penduduknya hidup dalam kekafiran, umumnya beragama orang Yunani. Jemaat Kristen di Filipi tertekan karena tidak disukai sebab ajaran agamanya bertentangan dengan kepercayaan kaum mayoritas pada saat itu (Sosipater, 2010). Selain itu, adanya konflik yang terjadi di tengah jemaat pada saat itu, terdapat suatu perkara perselisihan antara dua orang perempuan yang memiliki pengaruh, Paulus menyadari bahwa perselisihan itu akan menjadi besar dan membahayakan kesatuan jemaat. Hal ini yang mendorong Paulus untuk menyurati mereka dan memberikan nasihat untuk berdamai.

Memulai pasal 2, Paulus memberikan nasihat kepada jemaat agar mereka sehati sepikir dalam satu kasih, satu jiwa, satu tujuan, dengan tidak mencari kepentingan diri sendiri atau puji-pujian yang sia-sia, melainkan hidup dengan kerendahan hati menganggap orang lain lebih utama dari pada dirinya sendiri. Nasihat ini disimpulkan Paulus sebagai sesuatu hal yang diharapkan akan menyempurnakan sukacitanya, dalam artian Paulus sangat berharap terjadinya perdamaian dan jalinan relasi yang harmonis, harapan ini juga menjadi faktor yang mendorong Paulus merujuk pada Kristus sebagai teladan jemaat.

Pada ayat 5, Paulus memberikan nasihat kepada jemaat untuk menaruh pikiran dan perasaan yang terdapat juga dalam Yesus Kristus, dalam bahasa aslinya tertulis demikian touto phronete en humin ho kai en Christou Iesou (milikilah pikiran ini di antara kamu yang juga ada pada Kristus Yesus) (Sutanto, 2006). Frasa pertama pada ayat ini adalah touto phroneite en humin (milikilah atau bersikaplah ini di antara kamu), pada frasa ini Paulus memberikan penekanan pada kata touto phroneite (bersikaplah ini) pertanda bahwa ayat ini merupakan saran penting kepada jemaat meskipun sedikit terkesan seperti perintah. Sebagai pendahuluan kata touto phroneite (bersikaplah ini) merupakan angin segar bagi jemaat Filipi untuk mengadopsi sebuah kerangka pikiran dan mengembangkannya pada kebiasaan yang diuraikan pada ayat sebelumnya.

Frasa touto phroneite en humin dapat diterjemahkan "berpikirlah demikian di (di 
antara) dirimu sendiri." Masalah sebenarnya bukan pada terjemahan secara harafiah, tetapi pada penafsiran dalam ayat ini sebagian terletak pada penyediaan kata kerja untuk klausa kata sifat ho kai en Christo Iesou (yang juga ada pada Kristus Yesus) dan sebagian lagi dalam pemahaman frasa en Christou Iesou secara alami akan berarti (dalam pribadi Kristus Yesus) (Bruce, 2011). Kata ho kai (yang juga) merujuk pada ayat sebelumnya yang menunjukkan bahwa Kristus mencontohkan kualitas yang sama dengan cara yang akan dijelaskan oleh Paulus pada ayat selanjutnya (Garland, 2006).

Ayat ini menjadi penghubung antara permohonan Paulus kepada jemaat untuk satu hati dengan deskripsi mengenai Kristus, hal ini ditegaskan pada terjemahan versi NIV yang berbunyi "dalam hubungan kalian dengan satu sama lain, miliki pola pikir yang sama seperti Kristus." (Cohick, 2013). Dalam hal mengatasi dosa menyayangi diri sendiri dan mengasihi diri sendiri, Paulus mengarahkan para pembacanya kepada pusat pengajaran kekristenan, yaitu pribadi Kristus sendiri. Dalam Kristus terdapat derajat Kristen yang mutlak, terdapat teladan yang mulia (Brill, 2003).

Dari pendapat di atas, disimpulkan bahwa ayat 5 dapat dipahami sebagai kalimat yang menjembatani para jemaat Filipi mengacu pada sentral dari sikap kristiani, yaitu Kristus, bisa dikatakan pada ayat ini Kristus dijadikan alat brain storming Paulus kepada jemaat. Tetapi untuk dapat memahami mindset Kristus secara utuh, harus dengan memahami deskripsi Kristus yang dijabarkan Paulus pada ayat-ayat berikutnya. Maka dari itu analisis sintaksis dan semantik pada pembahasan ini harus berlanjut pada ayat 6 dan 7.

Pada ayat 6, Paulus mulai mendeskripsikan Kristus, yang diawali dengan frasa hos en morphe Theo (yang dalam rupa/sifat Allah) (Sutanto, 2006), frasa ini menyambung ide pemikiran Paulus mengenai mindset Kristus pada ayat 5. Diawali dengan frasa "yang pada hakikatnya Tuhan." Partisip ini diterjemahkan sebagai "ada" terkait dengan kata kerja utama di klausa berikutnya, "mempertimbangkan atau tidak." Hubungan tersebut setidaknya telah dipahami dalam tiga cara berbeda: (1) konsesi, "meskipun dalam bentuk Tuhan"; (2) kausal, "justru karena (dia) ada dalam bentuk Tuhan"; atau (3) tidak langsung, "yang berada dalam kondisi yang berbentuk Tuhan". Partisip ini mungkin lebih tepat membawa pengertian kausal, menyarankan gagasan tentang keberadaan dalam esensi seseorang atau mengungkapkan realitas situasi (Cohick, 2013). Kata morphe (bentuk/rupa) adalah bagian terkecil yang mempunyai sifat intristik dan merupakan kata kerja yang kuat untuk menyatakan keberadaan Kristus yang secara kasat mata tidak terlihat seperti Allah, namun essensinya Dia adalah Allah. Jelas bahwa ayat ini memberikan asumsi bahwa Kristus adalah Allah, selain Allah siapakah yang dapat berada dalam rupa kemuliaan dan terang atau berpenampilan dalam rupa Allah (Hagelberg, 2009).

Dengan sudut pandang yang lebih tegas MacArthur menyatakan bahwa frasa hos en morphe Theo (yang dalam rupa/sifat Allah) menegaskan Yesus selamanya adalah Tuhan. Kata Yunani yang biasa digunakan untuk kata "menjadi" tidak digunakan di sini. Sebaliknya, Paulus memilih istilah lain yang menekankan esensi sifat seseorang, keadaan atau kondisinya yang berkelanjutan. Paulus juga bisa saja memilih salah satu dari dua kata Yunani yang artinya "rupa", tetapi ia memilih kata yang secara khusus menunjukkan sifat esensial, yang tidak berubah dari sesuatu, apa yang ada di dalam dan dari dirinya sendiri. Doktrin fundamental tentang keilahian Kristus selalu mencakup karakteristik penting ini (MacArthur, 2007). Apakah morphe menunjukkan keadaan Yesus yang sudah ada sebelumnya? Jawabannya jelas iya, karena memang sudah sepatutnya demikian, jika dilihat dengan pandangan yang lebih luas dari "kesetaraan dengan Tuhan," istilah morphe membawa pengertian bentuk dan karakterisitk eksternal dari objeknya (Cohick, 2013).

Frasa berikutnya adalah ouk harpagmon hegesatou tou einai isa Theo (tidak menganggap hal itu menjadi suatu rampasan) (Sutanto, 2006). Kata Yunani "harpagmon" dapat diterjemahkan dengan istilah "perampok", lebih tepatnya berarti "sesuatu yang disita oleh hasil perampokan." Kata ini akhirnya berarti apa pun yang digenggam, dipeluk, atau dihargai, dan karenanya kadangkadang diterjemahkan "digenggam" atau "dipegang". Meskipun Kristus memiliki semua hak istimewa, dan penghormatan keilahian yang tidak pernah dapat didiskualifikasi dari dirinya, tetapi Dia bersikap bukan untuk berpegang teguh 
pada hal-hal itu atau berdiam dalam posisi semestinya, melainkan Dia bersedia untuk menyerahkannya (MacArthur, 2007). Kata harpagmon telah menjadi bahan perdebatan para ahli sebelumnya, akan tetapi banyak ahli yang sudah menyatakan sikapnya bahwa kata ini lebih tepat untuk diartikan sebagai "tindakan merebut," sehingga kesan yang didapat adalah bahwa Kristus tidaklah perlu merebut kesetaraan dengan Allah, tetapi cukup dengan memberikan apa yang ada pada-Nya dan itu yang membuat Kristus memperoleh kesetaraan dengan Allah (Gundry, 2011).

Dalam ayat 7, tindakan Kristus yang tidak menganggap hak-Nya yang serupa dengan Allah bukanlah sesuatu yang harus dipertahankan, diperjelas dengan sebuah kata "mengosongkan diri." Dalam kalimat utuh pada bahasa aslinya adalah alla heauton ekenosen morphe doulou labon, en homouiomati anthropon genomenos kai skemati euretheis hos anthropos (melainkan diri-Nya sendiri telah mengosongkan dan mengambil rupa seorang hamba, dalam kesamaan dengan manusia-manusia ditemui dalam wujud menjadi sebagai manusia) (Sutanto, 2006). Kata alla (tetapi) di sini memiliki kekuatan yang berlawanan dan harus ditekankan. Yesus menolak untuk mengeksploitasi status ilahi atau menggunakannya sebagai kesempatan untuk membesarkan diri. Dia memikul salib, bukan mahkotanya. Baginya persamaan dengan Tuhan berarti melepaskan hak istimewa, mengosongkan dirinya, melayani sebagai budak, menghabiskan dirinya, berlaku taat kepada Tuhan, dan menatap kematian seorang budak di kayu salib. Menjadi setara dengan Tuhan berarti menjadikan dirinya bukan apa-apa dan memberi daripada mendapatkan, dan pemberiannya atas dirinya mengungkapkan sifat alami (Garland, 2006).

Frasa selanjutnya adalah heauton ekenosen yang akrab diterjemahkan "mengosongkan diri." Dalam perkembangan ilmu teologi, kata ini adalah hal yang mendasari teori kenosis yang artinya Kristus memilih untuk membatasi diri dengan kerelaan saat datang ke bumi dan memastikan diri untuk taat menjalani misi-Nya sebagai manusia (Wellum, 2016). Yesus mengosongkan dirinya sendiri menjelaskan apa yang diwujudkan dalam rupa Allah dan setara dengan Allah, akan tetapi hal itu menimbulkan pertanyaan besar, dari apa Yesus mengosongkan dirinya?
Paulus tidak sedang membayangkan bahwa Kristus melepaskan diri dari kodrat ilahi-Nya, dan bagaimana seseorang sedang mengesampingkan sifatnya? Kata kerja kenoo digunakan oleh Paulus di tempat lain yang diartikan "menjadi tidak berdaya," atau "dikosongkan dari signifikansi." Pengertian ini paralel dengan ayat 8, "dia merendahkan dirinya sendiri." Paulus tidak berpikir bahwa Kristus sementara waktu mengesampingkan sifat-sifat ketuhanannya dengan tujuan untuk menang kembali. Mengosongkan dirinya sendiri berarti bahwa Kritus membuat dirinya batal demi hukum dan melepaskan hak-hak istimewanya. Dia menunjukkan kebalikan dari kata "kesombongan" yaitu "kenodoxia" yang artinya "kesombongan sia-sia," yang menganggap kehormatan palsu untuk diri sendiri dan menegaskan harga diri seseorang atas tempat yang lain. Terjemahan KJV, "membuat dirinya tidak memiliki reputasi," menangkap maksud Paulus di ayat 7 ini (Garland, 2006).

Berikutnya hal yang menarik untuk dikaji adalah frasa morphe doulou (rupa hamba), setelah Paulus mengatakan Kristus yang dalam rupa Allah tidak menganggap kesetaraan itu menjadi sesuatu yang harus dipertahankan atau dirampas dan menjadi kosong, lalu merujuk pada keputusan untuk mengambil rupa hamba, merupakan sebuah paradoks. Kendatipun demikian, justru pada momen ini Tindakan Kristus untuk mengosongkan diri memiliki nilai yang begitu tinggi, Paulus menggunakan bentuk kata Yunani doulou (hamba) untuk menunjukkan esensi yang tepat sebagai hamba yang sejati, tindakan ini merupakan kepatuhan Kristus untuk melakukan kehendak Allah Bapa yang mengutusNya (MacArthur, 2007).

Dari penjabaran di atas, penulis menyimpulkan makna dari mindset Kristus yang dimaksud Paulus pada ayat 5. Para ahli biasanya memaknai dengan istilah kerendahan hati Kristus. Pembaca atau jemaat diarahkan karena motivasi kasih mereka, untuk memenuhi sukacita Paulus dengan mengadopsi sikap rendah hati terhadap orang lain sebagai hal yang lebih penting daripada diri mereka sendiri (2: 1-4), dimana sikap seperti ini juga ada dalam diri Kristus Yesus (2: 5), dan itu paling tepat bagi mereka sebagai orang-orang yang kudus dalam domain berada "di dalam Kristus Yesus" (Heil, 2010). 
Makna yang pertama terdapat pada tindakan Kristus yang dalam rupa Allah tidak merampas atau mempertahankan haknya. Berkaitan dengan nasihat Paulus kepada jemaat untuk sehati sepikir, satu tujuan dan tidak mementingkan diri sendiri atau mendapatkan pujian yang sia-sia, tindakan Kristus yang tidak berusaha untuk merampas dan mempertahankan haknya merupakan contoh yang tepat untuk mengatasi permasalahan jemaat Filipi yang masih berada pada fase untuk mendapatkan pujian atas semua tindakan dan perbuatan mereka. Makna yang kedua terletak pada tindakan Kristus yang "mengosongkan diri." Kristus yang serupa dengan Allah dengan rela menjadi sama dengan manusia, kerelaan seperti ini yang menjadi poin dalam benak Paulus untuk dimiliki oleh jemaat Filipi. Jika jemaat memiliki kerelaan untuk tidak menganggap dirinya lebih penting dari orang lain, maka kesatuan dalam satu tujuan dan keharmonisan dari sebuah persekutuan akan terjalin dengan baik, hal ini yang menjadi harapan dan kerinduan Paulus untuk menyempurnakan sukacitanya dalam Kristus. Makna yang ketiga adalah terletak pada tindakan Kristus yang "mengambil rupa seorang hamba." Bukan saja tentang kesetiaan, melainkan Paulus merujuk kepada sikap hamba yang tidak mementingkan diri sendiri, seorang hamba hanya tunduk pada perintah tuannya dan dengan rasa ingin menyenangkan hati tuannya pada saat dia bertindak.

Cara berfikir yang diperlihatkan oleh Yesus Kristus adalah dimana Ia tidak "menganggap" dirinya setara dengan Tuhan, dalam rupa Tuhan bukanlah sesuatu yang dapat dieksploitasi secara egois untuk keuntungan diri sendiri. Melainkan, Yesus mengosongkan "dirinya" dengan mengambil rupa seorang hamba. Menjadi seorang hamba adalah motivasi dan model bagi cara berpikir jemaat pada saat itu (2: 5), untuk "menganggap" satu sama lain lebih penting daripada "diri mereka sendiri," tanpa pamrih, serta masing-masing saling memperhatikan bukan untuk keuntungan "diri mereka sendiri" tetapi semua untuk keuntungan orang lain (2: 34). Mengikuti tuntunan Paulus dan Timotius (1: 1), jemaat Filipi harus menjadi "hamba" yang meniru pola pikir "hamba" seperti Kristus Yesus yang tidak mementingkan diri sendiri (2: 6-7) (Heil, 2010).

Konteks permasalahan jemaat Filipi bukan saja terletak pada lingkup internal komunitas jemaat Kristen pada saat itu, melainkan juga pada lingkup eksternal mereka. Jika makna dari mindset Kristus ini dapat diimplementasikan oleh jemaat Filipi maka dampaknya akan dirasakan oleh lingkup di luar komunitas mereka. Dengan demikian akan terjalin keharmonisan pada lingkup internal dan eksternal jemaat Filipi. Makna mindset Kristus yang dijabarkan di atas dapat diimplementasikan oleh gereja masa kini terkait untuk membangun kerukunan umat beragama, sebab akar konflik horizontal umat beragama adalah tidak adanya kerendahan hati dan kesadaran tentang beragama yang benar dari sumber yang tidak dapat dimengerti dan ketidaktahuan atau kekurangpahaman terhadap keyakinan ajaran agamanya sendiri, terlebih kepercayaan orang lain (Khotimah, 2011).

\section{Kesimpulan}

Kesimpulan yang dapat diambil dalam kajian tafsir surat Filipi 2 ayat 5 yang terkait dalam tema mengenai mindset Kristus sebagai landasan gereja dalam membangun kerukunan umat beragama adalah bahwa mindset Kristus merupakan solusi dalam membangun kesatuan jemaat, bahkan kesatuan gereja lintas denominasi, dan bahkan sampai kepada lintas agama-agama di Indonesia.

Gereja harus memiliki sikap untuk tidak menganggap apa yang menjadi haknya adalah sesuatu yang harus dipertahankan. Gereja harus memiliki sikap dengan kerelaan menganggap pihak lain lebih penting dari pada kepentingan gereja itu sendiri. Gereja harus memiliki sikap tidak mementingkan diri sendiri, siap melayani orang lain tanpa menghiraukan sesuatu yang ada pada dirinya. Poin-poin ini yang pada akhirnya akan menjawab pertanyaan bagaimana seharusnya kehadiran gereja dapat diterima secara utuh dan mampu untuk hidup berdampingan dalam konteks masyarakat majemuk? Kemudian bagaimana gereja dapat bekerjasama dengan lembaga agama lain, saling berupaya memperkecil ketegangan atau konflik keagamaan? Jika gereja meletakkan mindset Kristus sebagai landasan bertindak dan bersikap, maka niscaya akan terjalin kerukunan, keharmonisan dalam lingkup lintas denominasi gereja.

Demikian juga dalam konteks keindonesiaan. Gereja memiliki peran penting mewujudkan 
kerukunan umat beragama dalam konteks keindonesiaan. Gereja-gereja harus mulai terbuka terhadap realitas kemajukan yang ada di Indonesia, keterbukaan yang dimaksud adalah dengan menanamkan kepada jemaat mindset Kristus sebagai landasan mereka dalam bertindak dan bersikap kepada seluruh masyarakat Indonesia, baik dalam pekerjaan, bisnis, maupun dalam kehidupan bertetangga. Dengan demikian akan terajut nilai-nilai kebersamaan dalam perbedaan, sehingga akan mewujudkan keharmonisan dalam lingkup keberagaman suku dan agama di Indonesia.

\section{UCAPAN TERIMA KASIH}

Penulis berterimakasih kepada Institut Agama Kristen (IAKN) Palangkaraya yang telah memfasilitasi perpustakaan yang membantu penulis dalam mendapatkan referensi terkait penulisan artikel ini. Juga kepada Bapak Dr. Darius Dubut dan Deri Sutanto, M.Si yang menjadi teman diskusi selama penulisan artikel ini berlangsung. 
Arifianto, Y. A. (2020). Membangun Kerukunan Antarumat Beragama dan Implikasinya bagi Misi Kristen. HUPERETES Jurnal Teologi Dan Pendidikan Kristen, 40.

Aritonang, A. (2019). Peran Sosiologis Gereja Dalam Relasi Kehidupan Antar Umat Beragama Indonesia. Jurnal TeDeum, 9(1), 69.

Brill, J. W. (2003). Tafsiran Surat Filipi. Kalam Hidup.

Bruce, F. F. (2011). Understanding The Bible Commentary Series - Philippians. Baker Books.

Cohick, L. H. (2013). The Story Of God Bible Commentary-Philippians. Zondervan.

Garland, D. E. (2006). The Expositor's Bible Commentary-Ephesians, Phlippians, Colossians, Philemon. Zondervan.

Gundry, R. H. (2011). Commentary On Philippians. Zondervan.

Hagelberg, D. (2009). Tafsiran Surat Filipi dari Bahasa Yunani. Andi Offset.

Hakim, L. (2011). Pandangan Islam tentang Pluralitas dan Kerukunan Umat Beragama dalam Konteks Bernegara. Harmoni, X(1), 11.

Hale, L. (2016). Diutus ke Dalam Dunia Menyelisik Teologi Abineno dan Kontribusinya bagi gerejagereja di Indonesia. BPK Gunung Mulia.

Harahap, N. (2014). Penelitian Kepustakaan. Jurnal Iqra', 08(1), 68-73.

Heil, J. P. (2010). Philippians - Let Us Rejoice Being Conformed To Christ. Society of Biblical Literature.

Khotimah. (2011). Dialog dan Kerukunan Antar Umat Beragama. Jurnal Ushuluddin, 17(2), 214-224.

MacArthur, J. (2007). Philippians-Christ, The Source Of Joys and Strength. Nelson Books.

Marxsen, W. (2015). Pengantar Perjanjian Baru. BPK Gunung Mulia.

Sosipater, K. (2010). Etika Perjanjian Baru. Suara Harapan Bangsa.

74 Mindset Kristus Sebagai Landasan Gereja ...
Sutanto, H. (2006). Perjanjian Baru Interlinier Yunani-Indonesia dan Korkondansi Perjanjian Baru (PBIK). Lembaga Alkitab Indonesia.

Suwariyati, T. (2011). Kerukunan Umat Beragama di Kabupaten Sidoarjo Provinsi Jawa Timur. Harmoni, X(1), 88.

Titaley, J. A. (2013). Religiositas Di Alinea TigaPluralisme, Nasionalisme dan Transformasi Agama-Agama. Satya Wacana University Press.

Wellum, S. J. (2016). God The Son Incarnate. Crossway. 